\title{
New use of microsatellite instability analysis in endometrial cancer (Review)
}

\author{
HARUKO KUNITOMI, KOUJI BANNO, MEGUMI YANOKURA, TAKASHI TAKEDA, MOITO IIJIMA, \\ KANAKO NAKAMURA, MIHO IIDA, MASATAKA ADACHI, KEIKO WATANABE, YUSUKE MATOBA, \\ YUSUKE KOBAYASHI, EIICHIRO TOMINAGA and DAISUKE AOKI
}

Department of Obstetrics and Gynecology, Keio University School of Medicine, Tokyo 160-8582, Japan

Received March 8, 2017; Accepted June 26, 2017

DOI: $10.3892 / 01.2017 .6640$

\begin{abstract}
The increasing incidence of obesity and diabetes due to changes in diet, earlier menarche, delayed menopause, late marriage, and declining birth rate have resulted in an increase in the number of endometrial cancer cases over the last few decades. Although surgical therapy is sufficient for early endometrial cancer, there is no effective therapy for patients with advanced and recurrent endometrial cancer. The oncogenic mechanism of endometrial cancer involves microsatellite instability (MSI) caused by dysfunction of DNA mismatch repair genes in $30 \%$ of patients. Immune checkpoint inhibitors, including anti-programmed death (PD)-1 and anti-PD-ligand 1 antibodies, are of interest as novel anticancer drugs; however, these drugs are currently expensive, and there is a need to select patients who will benefit from their use. The use of MSI analysis as a predictive biomarker for the therapeutic efficacy of these drugs may be useful for reducing the costs of drug therapy.
\end{abstract}

\section{Contents}

1. Introduction

2. Classification of endometrial cancer by genetic alterations and MSI

3. MSI analysis as a predictive biomarker for the efficacy of immune checkpoint inhibitors

4. New modalities of MSI analysis and perspectives

5. Conclusion

Correspondence to: Dr Kouji Banno, Department of Obstetrics and Gynecology, Keio University School of Medicine, 35 Shinanomachi, Shinjuku-ku, Tokyo 160-8582, Japan

E-mail: kbanno@z7.keio.jp

Key words: microsatellite instability, endometrial cancer, mismatch repair, immune checkpoint inhibitor, biomarker

\section{Introduction}

Microsatellites are repeat sequences of one to several DNA bases. These sequences are used for forensic identification and paternity testing because they are polymorphic, occurring widely in both coding and non-coding regions. Repeat errors during DNA replication are likely to occur in these regions and are usually repaired by DNA mismatch repair (MMR) genes. In neoplastic lesions that develop due to aberration of this mechanism, the microsatellite repeat number in tumor tissues differs from that in normal tissues (1). This phenomenon is called microsatellite instability (MSI) and is closely related to carcinogenicity of hereditary tumors, including Lynch syndrome and others (Fig. 1). MSI analysis is currently performed as secondary screening for patients suspected for Lynch syndrome.

MMR function is lost in 20-30\% of patients with endometrial cancer $(2,3)$. Lynch syndrome accounts for approximately $25 \%$ of these cases, and the majority involve hypermethylation of $M L H 1$ promoter or somatic mutations of MMR genes (4). A recent study showed that MSI analysis is effective as a predictive biomarker for the effect of immune checkpoint inhibitors, which are new anticancer drugs, including anti-PD-1 antibody and anti-PD-L1 antibody (5). This suggests that MSI analysis may be useful as a biomarker for the effect of immunotherapy for endometrial cancer. In this article, the utility of MSI analysis in patients with endometrial cancer and new testing procedures are discussed.

\section{Classification of endometrial cancer by genetic altera- tions and MSI}

Bokhman classified endometrial cancer into type 1 and 2 (6). Type 1 is characterized by relatively young onset, well-differentiated tumor with high expression of estrogen receptor (ER), and good prognosis. Type 2 is typically elderly-onset, ER-negative poorly differentiated cancer with a poor prognosis. Histologically, endometrioid adenocarcinoma has the highest incidence, followed by serous adenocarcinoma and clear cell adenocarcinoma. Type 1 cases are mostly well-differentiated endometroid adenocarcinoma, and Type 2 often involves other histological types $(7,8)$. PTEN, KRAS, CTNNB1 and PI3KCA mutations are frequently found in type 1 cases, whereas 
HER 2 and TP53 mutations occur in type 2 (7-10). Although there are certain tendencies for mutated genes (11-13), the Bokhman classification is limited by its difficulty in classification of endometrial cancer associated with MSI and Lynch syndrome $(2,3)$.

Using exome sequencing, The Cancer Genome Atlas Research Network categorized endometrial cancer into 4 types based on gene mutation pattern and frequency, copy number variation, and MSI status (13). These four types are referred to as POLE ultramutated, MSI hypermutated, copy-number low and copy-number high (Table I), and the incidences are 7.3, $28.0,38.8$ and $25.9 \%$, respectively. All tumors categorized in the POLE ultramutated group carry mutations in the exonuclease domain of POLE, and possessed the highest incidence of other gene mutations such as PTEN, PIK3R1 and PIK3CA. The copy-number low and high groups both have the lowest gene mutation rate and are categorized into two groups based on the existence of somatic copy number alterations. Distinct from these other types, the MSI type showed hypermethylation, which were mostly found in the $M L H 1$ promoter region, and has the second highest incidence of gene mutation following the POLE ultramutation type. MSI-type endometrial cancer is histologically characterized by lymphocyte invasion and immunogenicity (2). Because $M L H 1$ promoter methylation is a somatic event which leads to sporadic endometrial cancer (14), the effectiveness of immunotherapy should be determined not only in Lynch syndrome-related endometrial cancers, but also in sporadic cases classified in the MSI hypermethylated group.

\section{MSI analysis as a predictive biomarker for the efficacy of immune checkpoint inhibitors}

Cancer cells have two mechanisms to avoid the host immune response; the first involving the cytotoxic T-lymphocyte-associated protein 4 (CTLA-4) pathway, and the second linked with programmed cell death-1 (PD-1) and PD ligand (PD-L1) (15). Activated T cells express PD-1, and its interaction with PD-L1 decreases T cell activity $(16,17)$. Physiologically, PD-L1 is expressed in organs related to immune tolerance, including the tonsils, lungs and placental syncytiotrophoblasts $(18,19)$. Expression of PD-L1 on the surface of tumor cells causes the tumor to avoid host T-cell activity (20). Therefore, blocking of the PD-1 interaction with PD-L1 in such cancers is likely to enhance the host immune response and have an antitumor effect (Fig. 2). This has been shown in malignant melanoma and non-small-cell cancer, and an effect on ovarian cancer has been found in gynecological diseases $(20,21)$.

Le et al conducted a phase 2 study using an anti-PD-1 antibody, pembrolizumab, given every two weeks at $10 \mathrm{mg} / \mathrm{kg}$ in 11 patients with colon cancer associated with MMR deficiency (group A), 21 patients with colon cancer without MMR aberration (group B), and 9 non-colorectal cancer patients with MMR deficiency (group C) (5). The objective response rate (ORR) and 20-week progression-free survival (PFS) were 40 and $78 \%$ in group A, 0 and $11 \%$ in group B, and 71 and $67 \%$ in group C. Median PFS and overall survival (OS) could not be examined in group A, but were 2.2 and 5.0 months, respectively, in group $\mathrm{B}$. Compared to group $\mathrm{B}$, the patients in group A had significantly lower hazard ratios of $0.10(\mathrm{P}<0.001)$ for disease progression and $0.22(\mathrm{P}=0.05)$ for death. Exome

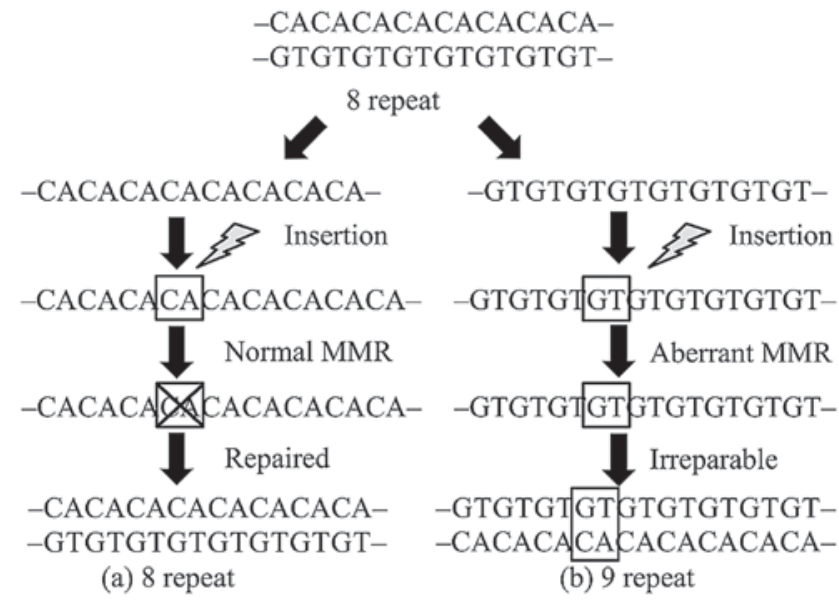

Figure 1. MSI is caused by aberrant MMR genes. (a) Even if insertion occurs during DNA replication, the microsatellite repeat number is repaired by the MMR mechanism and generally returns to the original value. (b) If the MMR mechanism is dysfunctional due to MMR gene aberrations, the insertion is not repaired and the repeat number increases. These variations of microsatellite repeat numbers that are not repaired due to replication errors caused by MMR gene aberrations are referred to as MSI. MSI, microsatellite instability; MMR, mismatch repair.

sequencing showed that group B (wild-type MMR function) had significantly fewer somatic mutations than groups $\mathrm{A}$ and $\mathrm{C}$ (MMR deficient) (73 vs. 1778, $\mathrm{P}=0.007$ ).

Although confirmation by phase 3 trials needs to be awaited, the results above suggest that anti-PD-1 antibody may be a new therapeutic candidate in cancer patients with aberrant MMR genes. Howitt et al found that MSI-type endometrial cancer had 7-fold higher neoepitope levels in comparison with microsatellite-stable (MSS) cancer (22). In POLE- and MSI-type cancers, the number of CD3- and CD8-positive cells invading cancer tissues was significantly higher than that in MSS-type cancer $(\mathrm{P}=0.001$ and $\mathrm{P}<0.001$, respectively), with no significant differences between POLE- and MSI-type cancers $(\mathrm{P}=0.86, \mathrm{P}=0.29)$ (22). Since the incidence of somatic mutation is high in tumors associated with MSI, it is suggested that proteins with new immunogenicity are produced in these tumors, leading to excessive $\mathrm{T}$ cell infiltration (23-25).

Expression of PD-L1 in tumors is not necessarily a precise marker to estimate the therapeutic effect of PD-1/PD-L1 checkpoint blockade (26), and the creation of a new strategy is imperative. MSI analysis may be a candidate predictive biomarker for the effect of immunotherapy, including immune checkpoint inhibitors.

\section{New modalities of MSI analysis and perspectives}

The Bethesda panel is the conventional approach for MSI analysis, which is optimized for the secondary screening of Lynch syndrome (27). This method uses a PCR assay at 5 microsatellites in total, consisting 3 dinucleotide repeats (D2S123, D5S346, D17S250) and 2 mononucleotide repeats (BAT26, BAT25), and determines differences in repeat number between tumor and non-tumor regions. Cases with $\geq 2,1$ and 0 positive markers are classified as MSI-high (MSI-H), MSI-low (MSI-L), and microsatellite stable (MSS), respectively. In the Bethesda panel, dinucleotide repeats 
Table I. Classification and characteristics of endometrial cancer [modified from (13)].

\begin{tabular}{|c|c|c|c|c|}
\hline & POLE (ultramutated) & MSI (hypermutated) & Copy number low & Copy number high \\
\hline Frequency & $7.3 \%$ & $28.0 \%$ & $38.8 \%$ & $25.9 \%$ \\
\hline Copy number aberrations & Low & Low & Low & High \\
\hline MSI status & Mixed & High & Stable & Stable \\
\hline Mutation rate & $\begin{array}{l}\text { Very high } 232 \times 10^{6} \\
\text { mutations } / \mathrm{Mb}\end{array}$ & $\begin{array}{l}\text { High } 18 \times 10^{6} \\
\text { mutations/Mb }\end{array}$ & $\begin{array}{l}\text { Low } 2.9 \times 10^{6} \\
\text { mutations/Mb }\end{array}$ & $\begin{array}{l}\text { Low } 2.3 \times 10^{6} \\
\text { mutations } / \mathrm{Mb}\end{array}$ \\
\hline Genes commonly mutated & $\begin{array}{c}\text { POLE }(100 \%) \\
\text { PTEN }(94 \%) \\
\text { PIK3CA }(71 \%) \\
\text { PIK3R1 }(65 \%) \\
\text { FBXW7 }(82 \%) \\
\text { ARIDIA }(76 \%) \\
\text { KRAS }(53 \%) \\
\text { ARID5B }(47 \%)\end{array}$ & $\begin{array}{c}\text { PTEN }(88 \%) \\
\text { RPL22 }(37 \%) \\
\text { KRAS }(35 \%) \\
\text { PI3CA }(54 \%) \\
\text { PIK3R1 }(40 \%) \\
\text { ARIDIA }(37 \%)\end{array}$ & $\begin{array}{c}\text { PTEN }(77 \%) \\
\text { CTNNB1 }(52 \%) \\
\text { PIK3CA }(53 \%) \\
\text { PIK3R1 }(33 \%) \\
\text { ARIDIA }(42 \%)\end{array}$ & $\begin{array}{c}\text { TP53 }(92 \%) \\
\text { PPP2RIA }(22 \%) \\
\text { PIK3CA }(47 \%)\end{array}$ \\
\hline Histological type & Endometrioid & Endometrioid & Endometrioid & $\begin{array}{l}\text { Endometrioid, } \\
\text { Serous, mixed }\end{array}$ \\
\hline Tumor grade & Mixed (grade 1-3) & Mixed (grade 1-3) & Grade 1 and 2 & Grade 3 \\
\hline Progression-free survival & Good & Intermediate & Intermediate & Poor \\
\hline
\end{tabular}

Mb, megabase.

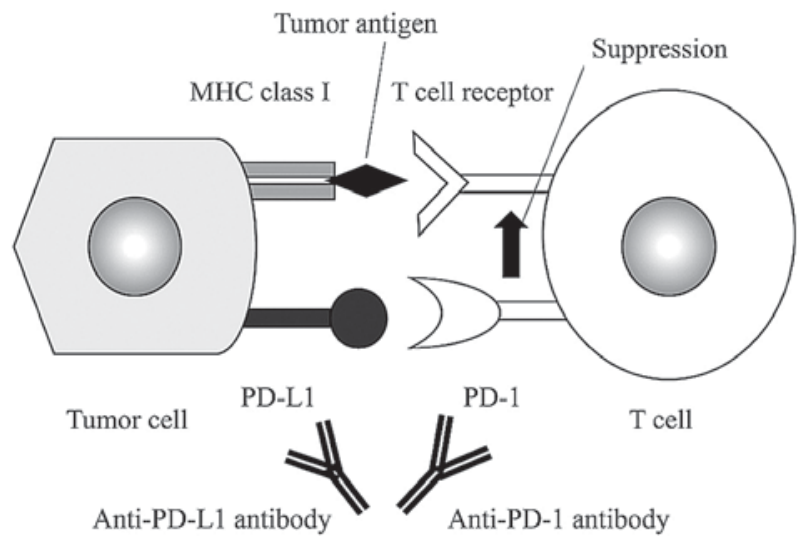

Figure 2. Action of antibodies against PD-L1 and PD-1 in tumor cells. Binding of PD-L1 expressed in tumor cells and PD-1 on the surface of T cells induces immune tolerance. Anti-PD-L1 antibody and anti-PD-1 antibody bind to PD-L1 and PD-1, respectively, to block immune tolerance, resulting in an enhanced antitumor effect of T cells.

have been shown to have less sensitivity and specificity than mononucleotide repeats (28), with particularly low sensitivity in patients with non-colorectal cancer, or tumors related to MSH6 mutation (29-33). Consequently, the pentaplex panel was developed as a procedure with higher sensitivity and specificity, and has been proposed as a replacement for the Bethesda panel (28,33-38). This panel uses 5 mononucleotide repeats (NR-21, NR-22, NR-24, BAT-25, BAT-26) as markers. A modified pentaplex panel with replacement of NR-22 with NR-27 is also used (39). Pagin et al developed a hexaplex panel method using 6 mononucleotide repeats (NR-21, NR-22, NR-27, BAT-25, BAT-26, BAT-40) as markers and showed that this approach had higher sensitivity and specificity than the pentaplex panel in patients with MSH6 mutation and those with non-colorectal cancer (40)

The type of microsatellite marker that is most appropriate for MSI analysis remains uncertain. Upon consideration of the use of MSI analysis as a predictive biomarker for the effect of anticancer drugs in endometrial cancer, the development of an optimal method for MSI detection in endometrial cancer, due to both somatic mutation and Lynch syndrome, is required. Hause et al developed the MOSAIC method for cross-sectional MSI analysis in 18 cancer types using the cancer exomes from the Cancer Genome Atlas (TCGA) database (41). In this model, a total of 223,082 microsatellites from exome sequencing were investigated to estimate mean mutation numbers in tumor and normal tissues obtained from cancer cases in the database. 17,564 microsatellites were identified as loci especially unstable in MSI-H tumors, which were located frequently in known oncogenes, suggesting that the other loci may also be located in so far unknown oncogenes. Characteristic microsatellite regions were involved among specific types of cancer, which distinguished four cancer-specific signatures based on MSI patterns. The MOSAIC method had a high sensitivity and specificity in identifying MSI-H tumors, with a possibly higher diagnostic accuracy in endometrial cancer compared to conventional MSI panels. The incidence of MSI-H tumor was highest in endometrial cancer among 18 types of tumors.

There is an ongoing debate about the methods for MSI analysis that can include results for unknown MMR genes in endometrial cancer. Therefore, the method proposed by Hause et al (41) may be an effective new approach with wider application compared to current MSI analysis optimized for Lynch syndrome. 


\section{Conclusion}

MSI is found in approximately $30 \%$ of cases of endometrial cancer. Immunotherapy is a promising therapeutic strategy for MSI-type endometrial cancer; however, this therapy is very expensive and there is a need to select patients who will benefit from the therapy. The current MSI assay is optimized for Lynch syndrome, whereas many cases of MSI-type endometrial cancer are caused by $M L H 1$ promoter methylation or somatic mutation, and a new method of MSI analysis focused on these cancers is needed. MSI analysis for advanced endometrial cancer may contribute to establishment of new therapeutic strategies, including neoadjuvant therapy, for patients with this cancer.

\section{Acknowledgments}

We thank Dr E. Sou (Keio University School of Medicine) for helpful assistance. The authors gratefully acknowledge support from the Keio Gijyuku Academic Development Fund. The funders had no role in data collection and analysis, decision to publish, or preparation of the manuscript.

\section{References}

1. Thibodeau SN, Bren G and Schaid D: Microsatellite instability in cancer of the proximal colon. Science 260: 816-819, 1993.

2. Karamurzin Y and Rutgers JK: DNA mismatch repair deficiency in endometrial carcinoma. Int J Gynecol Pathol 28: 239-255, 2009.

3. Murali R, Soslow RA and Weigelt B: Classification of endometrial carcinoma: More than two types. Lancet Oncol 15 e268-e278, 2014.

4. Garg K and Soslow RA: Lynch syndrome (hereditary non-polyposis colorectal cancer) and endometrial carcinoma. J Clin Pathol 62: 679-684, 2009.

5. Le DT, Uram JN, Wang H, Bartlett BR, Kemberling H, Eyring AD, Skora AD, Luber BS, Azad NS, Laheru D, et al: PD-1 blockade in tumors with mismatch-repair deficiency. N Engl J Med 372: 2509-2520, 2015.

6. Bokhman JV: Two pathogenetic types of endometrial carcinoma. Gynecol Oncol 15: 10-17, 1983.

7. Dedes KJ, Wetterskog D,Ashworth A, Kaye SB and Reis-Filho JS: Emerging therapeutic targets in endometrial cancer. Nat Rev Clin Oncol 8: 261-271, 2011.

8. Matias-Guiu X and Prat J: Molecular pathology of endometrial carcinoma. Histopathology 62: 111-123, 2013.

9. Salvesen HB, Haldorsen IS and Trovik J: Markers for individualised therapy in endometrial carcinoma. Lancet Oncol 13: e353-e361, 2012.

10. Weigelt B and Banerjee S: Molecular targets and targeted therapeutics in endometrial cancer. Curr Opin Oncol 24 554-563, 2012.

11. McConechy MK, Ding J, Cheang MC, Wiegand KC, Senz J, Tone AA, Yang W, Prentice LM, Tse K, Zeng T, et al: Use of mutation profiles to refine the classification of endometrial carcinomas. J Pathol 228: 20-30, 2012.

12. Urick ME, Rudd ML, Godwin AK, Sgroi D, Merino M and Bell DW: PIK3R1 (p85 $\alpha$ ) is somatically mutated at high frequency in primary endometrial cancer. Cancer Res 71: 4061-4067, 2011.

13. Cancer Genome Atlas Research Network, Kandoth C, Schultz N, Cherniack AD, Akbani R, Liu Y, Shen H, Robertson AG, Pashtan I, Shen R, et al: Integrated genomic characterization of endometrial carcinoma. Nature 497: 67-73, 2013.

14. Le Gallo $M$ and Bell DW: The emerging genomic landscape of endometrial cancer. Clin Chem 60: 98-110, 2014.

15. Mellman I, Coukos G and Dranoff G: Cancer immunotherapy comes of age. Nature 480: 480-489, 2011.

16. Freeman GJ, Long AJ, Iwai Y, Bourque K, Chernova T, Nishimura H, Fitz LJ, Malenkovich N, Okazaki T, Byrne MC, et al: Engagement of the PD-1 immunoinhibitory receptor by a novel B7 family member leads to negative regulation of lymphocyte activation. J Exp Med 192: 1027-1034, 2000.
17. Okazaki T and Honjo T: PD-1 and PD-1 ligands: From discovery to clinical application. Int Immunol 19: 813-824, 2007.

18. Dong H, Strome SE, Salomao DR, Tamura H, Hirano F, Flies DB, Roche PC, Lu J, Zhu G, Tamada K, et al: Tumor-associated B7-H1 promotes T-cell apoptosis: A potential mechanism of immune evasion. Nat Med 8: 793-800, 2002.

19. Keir ME, Butte MJ, Freeman GJ and Sharpe AH: PD-1 and its ligands in tolerance and immunity. Annu Rev Immunol 26: 677-704, 2008

20. Hamanishi J, Mandai M, Matsumura N, Abiko K, Baba T and Konishi I: PD-1/PD-L1 blockade in cancer treatment: Perspectives and issues. Int J Clin Oncol 21: 462-473, 2016.

21. Hamanishi J, Mandai M, Ikeda T, Minami M, Kawaguchi A, Murayama T, Kanai M, Mori Y, Matsumoto S, Chikuma S, et al: Safety and antitumor activity of anti-PD-1 antibody, nivolumab, in patients with platinum-resistant ovarian cancer. J Clin Oncol 33: 4015-4022, 2015.

22. Howitt BE, Shukla SA, Sholl LM, Ritterhouse LL, Watkins JC, Rodig S, Stover E, Strickland KC, D'Andrea AD, Wu CJ, et al: Association of polymerase e-mutated and microsatellite-instable endometrial cancers with neoantigen load, number of tumor-infiltrating lymphocytes, and expression of PD-1 and PD-L1. JAMA Oncol 1: 1319-1323, 2015.

23. Dudley JC, Lin MT, Le DT and Eshleman JR: Microsatellite instability as a biomarker for PD-1 blockade. Clin Cancer Res 22: 813-820, 2016.

24. Mills AM, Liou S, Ford JM, Berek JS, Pai RK and Longacre TA: Lynch syndrome screening should be considered for all patients with newly diagnosed endometrial cancer. Am J Surg Pathol 38: 1501-1509, 2014

25. Mlecnik B, Bindea G, Angell HK, Maby P, Angelova M, Tougeron D, Church SE, Lafontaine L, Fischer M, Fredriksen T, et al: Integrative analyses of colorectal cancer show immunoscore is a stronger predictor of patient survival than microsatellite instability. Immunity 44: 698-711, 2016.

26. Meng X, Huang Z, Teng F, Xing L and Yu J: Predictive biomarkers in PD-1/PD-L1 checkpoint blockade immunotherapy. Cancer Treat Rev 41: 868-876, 2015.

27. de la Chapelle A and Hampel H: Clinical relevance of microsatellite instability in colorectal cancer. J Clin Oncol 28: 3380-3387, 2010.

28. Buhard O, Suraweera N, Lectard A, Duval A and Hamelin R: Quasimonomorphic mononucleotide repeats for high-level microsatellite instability analysis. Dis Markers 20: 251-257, 2004.

29. Wu Y, Berends MJ, Mensink RG, Kempinga C, Sijmons RH, van Der Zee AG, Hollema H, Kleibeuker JH, Buys $\mathrm{CH}$ and Hofstra RM: Association of hereditary nonpolyposis colorectal cancer-related tumors displaying low microsatellite instability with MSH6 germline mutations. Am J Hum Genet 65: 1291-1298, 1999.

30. Hartmann A, Zanardo L, Bocker-Edmonston T, Blaszyk H, Dietmaier W, Stoehr R, Cheville JC, Junker K, Wieland W, Knuechel R, et al: Frequent microsatellite instability in sporadic tumors of the upper urinary tract. Cancer Res 62: 6796-6802, 2002.

31. Kuismanen SA, Moisio AL, Schweizer P, Truninger K, Salovaara R, Arola J, Butzow R, Jiricny J, Nyström-Lahti M and Peltomäki P: Endometrial and colorectal tumors from patients with hereditary nonpolyposis colon cancer display different patterns of microsatellite instability. Am J Pathol 160: 1953-1958, 2002.

32. Hendriks YM, Wagner A, Morreau H, Menko F, Stormorken A, Quehenberger F, Sandkuijl L, Møller P, Genuardi M, Van Houwelingen $\mathrm{H}$, et al: Cancer risk in hereditary nonpolyposis colorectal cancer due to MSH6 mutations: Impact on counseling and surveillance. Gastroenterology 127: 17-25, 2004.

33. You JF, Buhard O, Ligtenberg MJ, Kets CM, Niessen RC, Hofstra RM, Wagner A, Dinjens WN, Colas C, Lascols O, et al: Tumours with loss of MSH6 expression are MSI-H when screened with a pentaplex of five mononucleotide repeats. Br J Cancer 103: 1840-1845, 2010.

34. Suraweera N, Duval A, Reperant M, Vaury C, Furlan D, Leroy K, Seruca R, Iacopetta B and Hamelin R: Evaluation of tumor microsatellite instability using five quasimonomorphic mononucleotide repeats and pentaplex PCR. Gastroenterology 123: 1804-1811, 2002.

35. Umar A, Boland CR, Terdiman JP, Syngal S, de la Chapelle A, Rüschoff J, Fishel R, Lindor NM, Burgart LJ, Hamelin R, et al: Revised Bethesda Guidelines for hereditary nonpolyposis colorectal cancer (Lynch syndrome) and microsatellite instability. J Natl Cancer Inst 96: 261-268, 2004. 
36. Wong YF, Cheung TH, Lo KW, Yim SF, Chan LK, Buhard O, Duval A, Chung TK and Hamelin R: Detection of microsatellite instability in endometrial cancer: Advantages of a panel of five mononucleotide repeats over the National Cancer Institute panel of markers. Carcinogenesis 27: 951-955, 2006.

37. Xicola RM, Llor X, Pons E, Castells A, Alenda C, Piñol V, Andreu M, Castellví-Bel S, Payá A, Jover R, et al: Performance of different microsatellite marker panels for detection of mismatch repair-deficient colorectal tumors. J Natl Cancer Inst 99: 244-252, 2007.

38. Goel A, Nagasaka T, Hamelin R and Boland CR: An optimized pentaplex PCR for detecting DNA mismatch repair-deficient colorectal cancers. PLoS One 5: e9393, 2010.
39. Buhard O, Cattaneo F, Wong YF, Yim SF, Friedman E, Flejou JF, Duval A and Hamelin R: Multipopulation analysis of polymorphisms in five mononucleotide repeats used to determine the microsatellite instability status of human tumors. J Clin Oncol 24: 241-251, 2006.

40. Pagin A, Zerimech F, Leclerc J, Wacrenier A, Lejeune S, Descarpentries C, Escande F, Porchet $\mathrm{N}$ and Buisine MP: Evaluation of a new panel of six mononucleotide repeat markers for the detection of DNA mismatch repair-deficient tumours. Br J Cancer 108: 2079-2087, 2013.

41. Hause RJ, Pritchard CC, Shendure J and Salipante SJ: Classification and characterization of microsatellite instability across 18 cancer types. Nat Med 22: 1342-1350, 2016. 